\title{
Political Repressions at Leningrad State University
}

\author{
A. L. Belonogov
}

For citation: Belonogov A. L. Political Repressions at Leningrad State University. Vestnik of Saint Petersburg University. History, 2020, vol. 65, issue 4, pp. 1085-1106.

https://doi.org/10.21638/11701/spbu02.2020.404

This article analyses socio-biographical characteristics of the Leningrad State University (LGU) teaching staff, subjected to political repressions from 1935 to 1938. It determines the scale of repressions in LGU during the abovementioned period as well as identifies the groups of University teachers who were exposed to the highest risk of being repressed, taking into consideration their social background, party membership, ethnic origin, position in the University ranks, affiliation with a certain faculty or department, and other socio-biographical characteristics. Thus "socio-demographic portrait" of an average LGU teacher subjected to political repressions is formed within the framework of the current study. Apart from that, the article discusses the course of investigation and court proceedings, defining under which paragraph of Article 58 of RSFSR Criminal Code LGU teachers were sued. It specifies to what extent the severity of the verdict depended upon pleading guilty or not guilty by the accused, and upon which judicial or extrajudicial body the case was heard. Evidential basis used by investigators, including physical evidence, denunciations, incriminations and self-incriminations are also examined within this study. The efforts of NKVD to "reclassify" meetings between groups of fellow professors as "counterrevolutionary collusions of terrorists" are also considered in the article. At the same time, the article attempts to estimate the level of physical and psychological pressure to which suspects were exposed in the course of the trial in order to obtain from them the testimony needed for the prosecution. The study also traces the fate of the convicted LGU professors, namely the likelihood of them becoming the victims of subsequent political repressions after serving the sentence.

Keywords: political repressions, Leningrad State University (LGU), teachers, socio-biographical characteristics, extrajudicial NKVD bodies, counterrevolutionary terrorist organizations, expedited trial proceedings, arrested, Special Council of the NKVD, Special troika.

\section{Политические репрессии в Ленинградском государственном университете}

\section{А. Л. Белоногов}

Для цитирования: Belonogov A.L. Political Repressions at Leningrad State University // Вестник Санкт-Петербургского университета. История. 2020. Т. 65. Вып. 4. С. 1085-1106.

https://doi.org/10.21638/11701/spbu02.2020.404

В данной статье проводится социально-биографический анализ профессорско-преподавательского состава Ленинградского государственного университета, подвергнутого

Andrey L. Belonogov - PhD (Political Science), Senior Lecturer, St. Petersburg State University, 7-9, Universitetskaya nab., St. Petersburg, 199034, Russian Federation; a.belonogov@spbu.ru

Андрей Львович Белоногов - канд. полит. наук, ст. преп., Санкт-Петербургский государственный университет, Российская Федерация, 199034, Санкт-Петербург, Университетская наб., 7-9; a.belonogov@spbu.ru

(C) St. Petersburg State University, 2020 
политическим репрессиям в период с 1935 по 1938 г. В ней определяется масштаб политических репрессий в вузе в данный период, сделана попытка выявить, какие группы преподавателей имели наивысший риск оказаться среди репрессированных, учитывая их пол, возраст, социальное происхождение, партийную принадлежность, национальность, должность и место в служебной иерархии, специальность (факультет или кафедру, к которой они были приписаны), а также другие социально-биографические показатели. Тем самым формируется так называемый «усредненный демографический портрет» репрессированного преподавателя университета. Кроме того, в статье рассматривается ход следствия и судебного разбирательства, характерный для политических процессов 1930-х гг., - определяется, какие пункты ст. 58 Уголовного кодекса РСФСР инкриминировались преподавателям вуза, насколько жесткость вынесенного приговора зависела от признания обвиняемым своей вины и от того, каким органом (судебным или внесудебным) рассматривалось дело. Помимо этого, анализируется доказательная база, которую использовало следствие, в том числе доносы, оговоры и самооговоры, вещественные доказательства по делу и обличительные показания других обвиняемых. Рассматривается целенаправленная работа органов НКВД над тем, чтобы встречи преподавателей в служебной и частной обстановке трактовались как «контрреволюционные совещания террористов и заговорщиков». В статье оценивается, в какой степени к обвиняемым применялись различного рода меры физического и психологического воздействия, включая пытки, с целью получения нужных для следственных органов показаний. Прослеживается дальнейшая судьба репрессированных преподавателей, а именно вероятность стать жертвами политических репрессий в последующие годы, получив повторный срок после освобождения из мест лишения свободы.

Ключевые слова: политические репрессии, Ленинградский государственный университет (ЛГУ), преподаватели, социально-биографические характеристики, внесудебные органы НКВД, контрреволюционные террористические организации, ускоренное судопроизводство, арестованные, Особое совещание при НКВД СССР, Особая тройка.

In recent years, the issue of political repressions in the USSR, which culminated during so-called "Great Terror" in 1937-1938, has been often raised in Russian historical studies. Some of these works concern repressions in Leningrad as a whole ${ }^{1}$, repressions in certain educational institutions of Leningrad ${ }^{2}$ as well as repressions against individual academics and scholars ${ }^{3}$. In this respect the studies of the Russian historian V.S. Brachev, which are dedicated to the fate of repressed LGU teachers such as M.M. Tsvibak ${ }^{4}$,

${ }^{1}$ Amosova A. A. Reabilitatsiia zhertv politicheskikh repressii (na materialakh "leningradskogo dela") // Noveishaia istoriia Rossii. 2011. No. 1. P. 153-159.

2 See, for example: Repressirovannye politekhniki / eds V.A.Smelov, N. N. Storonkin. St. Petersburg, 2008; Korsakov S. N. Politicheskie repressii v institute filosofii (1930-1940-e gg.) // Filosofskii zhurnal. 2012. No. 1(8). P. 120-170; Tragicheskie sud'by: repressirovannye uchenye Akademii nauk SSSR // Ros. AN, Otdnie istorii, Arkh. RAN / ed. by I. G. Aref'eva. Moscow, 1995; etc.

3 Skvortsov A.M. Razgrom "antichnogo kruzhka" v Leningrade: (po materialam sledstvennykh del arkhiva FSB) // Vestnik drevnei istorii. 2017. Vol.77, no. 1. P.210-223; Gessen V.Iu. Aleksandr Alekseevich Voznesenskii - rektor Leningradskogo universiteta s tragicheskoi sud'boi // Mavrodinskie chteniia - 2018. Materialy Vserossiiskoi nauchnoi konferentsii, posviashchennoi 110-letiiu so dnia rozhdeniia professora Vladimira Vasil'evicha Mavrodina / ed. by A. Yu. Dvornichenko. St. Petersburg, 2018, P. 598-602; Ofitsial'nye dannye o sud'be pulkovskikh astronomov // Na rubezhakh poznaniia Vselennoi (Istoriko-astronomicheskie issledovaniia, XXII). Moscow, 1990, P. 482-490; Andreeva V. V. Zabytoe imia: sud'ba molodogo istorika i etnografa Evgeniia (Eina) Solomonovicha Leibovicha (1907-1937) // Akademik A.S. Lappo-Danilevskii v pamiati nauchnogo soobshchestva / eds V. V. Kozlovskii, A. V. Malinov. St. Petersburg, 2019. P. 646-656.

${ }^{4}$ Brachev V.S. Istorik M. M. Tsvibak i ego sud'ba (1899-1937 gg.) // Obshchestvo. Sreda. Razvitie. 2008. No. 2 (7). P.33-54. 
Ya. M.Sacher ${ }^{5}$, N.I. Ulyanov ${ }^{6}$, S. F. Platonov ${ }^{7}$, V.N. Kashin ${ }^{8}$, I. M. Trotsky ${ }^{9}$ and many others, are worth mentioning. However, a comprehensive study that would analyze political repressions at LGU as a whole has not yet appeared. The current article aims at filling this gap by analyzing to what extent political repressions affected the largest university of Leningrad and one of the largest universities in the country.

This article merely gives an approximate assessment of the scale of political repressions at Leningrad University in the 1930s as it is difficult to give precise figures based on available documents at the moment. In addition, it analyzes socially significant characteristics of repressed teachers on the basis of biographical information from their personal files that can be found in the Unified Archive of St. Petersburg State University. This analysis allows us to understand which groups of LGU teachers were more likely to become the victims of political repressions during this period of time. The examination of documents from the FSB Archive in Saint Petersburg and the Leningrad Region makes it possible to identify the mechanisms of political repressions at the University and to trace the course of investigation and decision-making by various judicial and extrajudicial bodies in relation to various groups of teachers. Another group of sources used in the current study are the books of memory or so-called "martyrologies" - lists of repressed scientists with a brief biographical description ${ }^{10}$. Memoirs of repressed teachers, of their University colleagues as well as testimonies of their relatives and contemporaries ${ }^{11}$ are also of interest within the framework of this article. The use of all the above-mentioned sources enables to identify the specific features and patterns of political repressions at LGU in the 1930s.

Chronologically the article covers four years - from the beginning of 1935 to the end of 1938. It is during this period that the University was subjected to the most severe political repressions. The assassination of the First Secretary of the Leningrad Regional Committee of the All-Union Communist Party (Bolsheviks) ${ }^{12}$ and a member of the Politburo S.M. Kirov in December 1934 is used as a starting reference point in this study. This event was immediately followed by the campaign at LGU with a view to identifying "alien class elements" among teachers resulting in their subsequent dismissal and expulsion to other cities. As the final reference point the current article uses the end of 1938, when L.P. Beria replaced N. I. Ezhov as the head of the People's Commissariat for Internal Affairs (NKVD). Shortly thereafter, political repressions in the USSR began to slow down, and so-called "Special troikas" were dissolved on November 17, 1938.

5 Brachev V.S. "Delo" Ia. M. Zakhera // Obshchestvo. Sreda. Razvitie. 2012. No. 2 (23). P. 41-45.

6 Brachev V.S. "Delo" professora N. I. Ul'ianova (1904-1985 gg.) // Obshchestvo. Sreda. Razvitie. 2013. No. 2 (27). P. 53-57. 2005.

7 Brachev V.S. Krestnyi put' russkogo istorika. Akademik S. F. Platonov i ego “delo”. St. Petersburg,

${ }^{8}$ Brachev V.S. Istorik Vladimir Nikolaevich Kashin (1890-1938) // Obshchestvo. Sreda. Razvitie. 2019. No. 2 (51). P.3-9.

9 Brachev V.S. Istorik Isaak Moiseevich Trotskii (1903-1937) // Noveishaia istoriia Rossii. 2015. No. 3 (14). P. 69-79.

10 Repressirovannoe vostokovedenie: Vostokovedy, podvergshiesia repressiiam v 20-50-e gody / eds A. M. Grishina, Ia. V. Vasil'kov, F. F. Perchenok // Narody Azii i Afriki. 1990. No. 4. P. 113-125; Leningradskii martirolog. URL: http://visz.nlr.ru/person/book/t1 (accessed: 10.01.2020); Otkrytyi spisok. URL: https:// ru.openlist.wiki/ (accessed: 10.01.2020).

11 See, for example: Gornshtein L. Z. Nochnoi dnevnik. St. Petersburg, 2013; Yermolaev M. M. Vospominaniia. Mikhail Yermolaev (v soavtorstve s Tamaroi L’vovoi). Petrozavodsk, 2009.

12 Usually abbreviated as $\operatorname{VKP}(\mathrm{b})$. 
However, this does not mean that political repressions at LGU were taking place exclusively during the above-mentioned period. Of course, a peak of repressions occurred at the University in 1935-1938, but they went on in previous and subsequent years. Among the most high-profile trials were the "Academic Trial" of 1930 and the "Leningrad affair" of 1952, which also directly affected LGU teachers. Arrests did not stop even in 19411942 during the siege of Leningrad ${ }^{13}$. The statistics given in the article therefore cannot be considered exhaustive; it only outlines a general picture of the events that took place at LGU, and, most likely, will require additional adjustments in the future. Moreover, this study is exclusively focused on teaching staff of the University and does not analyze students, postgraduates, teaching support and technical staff of LGU.

In order to estimate the scale of political repressions at the University, it is necessary first of all to assess the total number of teachers who worked there during the period under review. According to the orders of the Director (Rector ${ }^{14}$ ) of LGU, where the lists of teachers' names are given, in the pre-war period the teaching staff ranged from 612 people (1935) to 949 people (1940) ${ }^{15}$. The University gradually expanded, and the number of teachers, as well as the number of faculties and departments, was increasing from year to year. In 1934, the Faculty of History was formed within the structure of LGU, which became the sixth faculty in a row, along with the Faculties of Physics, Geology, Soil and Geography, Mathematics, Chemistry and Biology. Subsequently, in 1937, the Faculty of Philology and Geography were added to this list (the latter was separated from the Faculty of Geology, Soil and Geography). By 1938, the University thus had a total of eight faculties, which in turn were divided into 72 departments ${ }^{16}$.

When assessing the scale of political repressions which affected LGU teachers, it is primarily necessary to compare the list of the teaching staff, which was announced before the beginning of each academic year by the orders of the Director of the University, and the annual number of dismissals under article 47 of the Labor Code of the RSFSR (the employees against whom criminal persecution was initiated were dismissed under this article). Table 1 below illustrates the statistical data on political repressions in LGU by year ${ }^{17}$. It should be noted that the last row in the table shows the total number of teachers who comprised the University staff during any of the four years considered in the study, i. e., taking into account the "turnover" and layoffs. According to the average indicators for the four-year period, the annual LGU staff turnover was approximately $10 \%$. This analysis considers the total number of dismissals of teachers from LGU that could occur for a variety of reasons, both related and unrelated to political repressions.

Based on this table, we can conclude that the largest number of teachers was arrested in 1937. It is noteworthy that while in 1935, immediately after the S. M. Kirov's as-

13 Sobolev G. L., Khodiakov M. V. Poteri Leningradskogo universiteta v gody Velikoi Otechestvennoi voiny // Vestnik Sankt-Peterburgskogo universiteta. History. 2010. Issue 2. P. 18-19.

${ }^{14}$ In the early 1930s the position of LGU Rector was renamed to the position of LGU Director. In 1937 the Director of LGU M. S. Lazurkin was criticized at the communist party meetings for still using the word "rector" in his conversations with the employees.

${ }^{15}$ Prikazy direktora po Lengosuniversitetu 1935-1940 gg. // Ob”edinennyi arkhiv SPbGU. F. 1. Op. 1. D. 24-92.

16 Prikazy direktora po Lengosuniversitetu 1937 g. // Ob“edinennyi arkhiv SPbGU. F. 1. Op. 1. D. 3847. D. 24-92.

17 Prikazy direktora po Lengosuniversitetu 1935-1940 gg. // Ob”edinennyi arkhiv SPbGU. F. 1. Op.1. 
Table 1. The scale of political repressions at LGU in 1935-1938

\begin{tabular}{|c|c|c|c|}
\hline Year & Number of teachers & Number of teachers repressed & \% of teachers repressed \\
\hline 1935 & 612 & 41 & 6,7 \\
\hline 1936 & 639 & 11 & 1,72 \\
\hline 1937 & 796 & 76 & 9,55 \\
\hline 1938 & 847 & 40 & 4,72 \\
\hline Total & $\mathbf{1 0 5 2}$ (in 4 years) & $\mathbf{1 6 8}$ & $\mathbf{1 5 , 9 7}$ \\
\hline
\end{tabular}

sassination, the main type of repression was the expulsion of unreliable employees from Leningrad (27 teachers were exiled, 14 were arrested ${ }^{18}$ ), in 1937 detention was almost always used as the main type of repression. Administrative exile in 1935 most often did not exclude the subsequent arrest in 1937 or in 1938, as it happened to a significant part of the exiled LGU teachers. Some of the former teachers detained in other cities were subsequently transferred to Leningrad for further investigation. For example, among the exiled teachers was the former Dean of the Faculty of History, G. S. Zaydel, who was returned to Leningrad from Saratov for court proceedings in 1937.

The comparison between the scale of political repressions in a single organization (LGU) and in the whole country can lead to a conclusion that the University teachers were affected to a much greater extent than other categories of Soviet citizens. This statement initially seems fairly obvious; however, it was interesting to find out to what extent the figures on repressions at LGU exceed the statistics on those in the Soviet Union as a whole: by several times, by several dozen times, or by an order of magnitude. In four years (1935-1938), according to an approximate estimation, about 1,5\% of the population of the USSR were convicted under article 58 of the RSFSR Criminal Code ${ }^{19}$, while at the University, as shown in Table 1, over the same period of time, the percentage of repressed teachers was at least 10 times higher and reached about $16 \%$ of the staff. This is due to the fact that the intellectual elite, which included LGU professorship, was subject to more thorough control and purges on the part of the Communist Party and NKVD bodies, and, as a result, University teachers were at higher risk of being among the repressed than average Soviet citizens.

It is also interesting to analyze the socio-demographic characteristics of repressed teachers in order to understand which of them increased and which decreased the chances of being subjected to political repressions. For this analysis, such parameters as age, gender, social origin, party affiliation, ethnicity, affiliation to a particular faculty, the status at LGU (title, position), etc. were used. All these characteristics are indicated in the personnel records of University employees that they filled out when applying for a job. Of course, it is possible that some of LGU employees may have intentionally specified incorrect bi-

18 Prikazy direktora po Lengosuniversitetu 1935 g. // Ob”edinennyi arkhiv SPbGU. F. 1. Op. 1. D. 24-29.

19 The number of citizens repressed in the USSR, convicted under article 58 of the Criminal Code of the RSFSR for "counterrevolutionary crimes" from 1935 to 1938, according to statistics of V.V.Luneev (Luneev V. V. Prestupnost' XX veka. Mirovye, regional'nye i rossiiskie tendentsii: mirovoi kriminologicheskii analiz. Moscow, 1997. P. 180), is about 2 million people. Based on these statistics, it can be estimated that in 4 years about $1,5 \%$ of Soviet citizens who reached the age of majority were repressed. 
ographical information in the documents, but it is unlikely that such misrepresentations were widespread: after all, this could result in quite serious sanctions, including dismissal from the University and exclusion from the ranks of the $\operatorname{VKP}(\mathrm{b})$. Therefore, in general, the reliability of socio-biographical characteristics indicated in the personnel records can be estimated as relatively high.

The analysis shows that men predominate among the repressed teachers as there were $88 \%$ of them in the University teaching staff subjected to political persecution ${ }^{20}$. Such gender characteristics of the staff of those times are not surprising since twenty years prior to it, in the pre-revolutionary years, there was only one woman - Maria Ostrovskaya who worked at the University. The increase in the number of women teachers in the 1930s indicates that during this period social "elevators" in the USSR operated much better than in the Russian Empire before, but there were still significantly more men among teachers.

The same conclusion can be drawn when analyzing the age structure of repressed teachers as quite often young professors aged 30-35 worked at LGU in the $1930 \mathrm{~s}^{21}$. Thus, the average age of teachers at the time of repressions was merely 41 years. This fact can be connected with two basic trends: firstly, with the gradual growth of the University, when former students were employed as teachers, and, secondly, with political repressions at LGU that freed positions for younger teachers. Thus, political repressions were one of the reasons of upward mobility at LGU, but not the only one: the 1930s were the time when the University staff also increased due to the establishment of new departments and faculties.

In terms of ethnic origin, the majority of repressed LGU teachers were Russians (57\%), and the second largest ethnic group was Jews (about $20 \% 22$ ). A large percentage of Jews among the repressed teachers can also be explained by the social mobility characteristic of the early USSR. After the official abolition of the Pale of Settlement in 1917, a significant number of Jews gained access to higher education in the 1920s and 1930s. At the same time, the initially higher level of literacy of Russian Jews compared to other ethnic groups in the Russian Empire gave them obvious advantages with regard to entering the University and becoming LGU professors afterwards.

In general, in the period under review the largest group of teachers in the LGU staff was the assistant lecturers ${ }^{23}$. For example, in 1936-1937 academic year, there were 161 full professors, 193 associate professors, and 292 assistant lecturers at LGU24. However, the majority among the repressed teachers were full professors (50 employees or 37\%); the second largest group was comprised of associate professors (42 employees or $31 \%$ ), while assistant and senior lecturers combined constituted a fewer proportion among repressed teachers - 35 employees or $26 \%^{25}$. Thus, the analysis of socio-biographical characteris-

20 See Personnel records of workers, employees, academic teaching staff dismissed in 1917-1941: Lichnye dela rabochikh, sluzhashchikh, professorsko-prepodavatel'skogo sostava, uvolennykh v 19171941 gg. // Ob”edinennyi arkhiv SPbGU. F. 1. Op. 3.

21 Ibid.

22 Ibid.

23 The lowest position of teachers in Soviet and Russian Universities.

24 Prikaz No. 1054/478 po Leningradskomu gosudarstvennomu universitetu im. A.S. Bubnova ot 27.12.1936, Prikazy direktora po Lengosuniversitetu No. 930-1086 // Ob”edinennyi arkhiv SPbGU. F. 1. Op. 1. D. 37. L. 196-212. - In this article a relatively small group of LGU senior lecturers was included into the group of assistant lecturers for ease of analysis.

25 See Personnel records of workers, employees, academic teaching staff dismissed in 1917-1941: Lichnye dela rabochikh, sluzhashchikh, professorsko-prepodavatel'skogo sostava, uvolennykh v 19171941 gg. // Ob"edinennyi arkhiv SPbGU. F. 1. Op. 3. 
tics suggests that those of the teachers who had the title of full professor or held the position of dean or head of department had the greatest risk of becoming victims of political repressions and were persecuted more often. During the period in question, a total of 4 deans (three of them were deans of the Faculty of History) and 26 heads of departments (out of 72) were repressed.

The analysis of the number of repressed teachers by faculties demonstrates that the Faculty of History was the most affected. This allows us to assume that being a historian at the University in 1930s was really a "suicide mission". In addition to this, a significant part of the teaching staff of such inter-faculty departments as the Departments of Leninism, Dialectical Materialism and Political Economy, which along with the Faculty of History were engaged in ideological work at LGU, was also repressed.

As for the teachers of natural science faculties, a large number of them were repressed within the so-called "Pulkovo Affair" from 1936 to 1938. According to the interrogation records of B. V. Numerov who was accused of being "the head of the fascist Trotskyist-Zinoviev terrorist organization" of Pulkovo astronomers and geophysicists, the latter included at least 30 members, with 13 of them being the teachers of LGU, predominantly from the Faculty of Physics. The counter-revolutionary organization itself had an extensive network: its "branches" were located in Astronomical Institutes in Leningrad and Moscow; in Pulkovo, Tashkent and Simeiz Observatories; in the Optical Institute and in the Central Research Institute of Geological Prospecting in Leningrad as well as in the Geophysical Office of "Razvedglavneft" in Moscow ${ }^{26}$.

Meanwhile, it can be possible that the figures on repressed teachers of the Military Department and of the Department of Physical Culture, provided in the current article, are understated and will require clarification in the future since the staff of these departments chiefly consisted of so-called "military experts", who were often considered "suspicious" by the NKVD bodies. As most of them made their careers under the old regime and were often of noble origins, they were perceived by the Soviet authorities as belonging to the enemy classes. However, the orders of the Director of LGU did not always specify the reasons for the dismissal of the teachers belonging to these departments, although it was likely that they were dismissed due to political repressions. The distribution of repressed teachers by faculty and by some departments is shown in Table $2^{27}$.

The social origin of teachers, which each of them indicated in the personnel records when applying for a job, is equally important for the current analysis. Most of the LGU teachers who were the victims of political repressions had petty bourgeoisie origin $(42 \%)^{28}$; the second large group of teachers had working-class or peasant background (put together they account for $27 \%$ of the total). As for the descendants of hereditary nobles (13\%), of the clergy (5\%), of the industrial bourgeoisie and merchants (4\%),

${ }^{26}$ Arkhivno-ugolovnoe delo Numerova B. V. // Arkhiv UFSB Rossii po SPb i LO. D.П-23060: in 4 vols. Vol. 1. L. 14-16.

27 See Personnel records of workers, employees, academic teaching staff dismissed in 1917-1941: Lichnye dela rabochikh, sluzhashchikh, professorsko-prepodavatel'skogo sostava, uvolennykh v 19171941 gg. // Ob"edinennyi arkhiv SPbGU. F. 1. Op. 3.

${ }_{28}$ This group also includes personal nobles and honorary citizens since their social status was closer to that of petty bourgeoisie than to the status of hereditary nobles, and in most cases they could not pass on their titles by inheritance. This category of teachers could also have indicated their social origin in the personnel records as "labor intelligentsia". 
their percentage among the repressed teachers was less significant. The distribution of repressed LGU teachers according to their social origin is shown in Table $3^{29}$.

Table 2. The distribution of repressed LGU teachers by faculties/departments

\begin{tabular}{|l|c|c|}
\hline \multicolumn{1}{|c|}{ Faculty } & Number of teachers repressed & \% of teachers repressed \\
\hline History & 40 & 24 \\
\hline Physics and Mathematics & 31 & 19 \\
\hline Geology, Soil and Geography & 29 & 17 \\
\hline Philology & 21 & 13 \\
\hline Biology & 10 & 6 \\
\hline Chemistry & 7 & 14 \\
\hline $\begin{array}{l}\text { Inter-faculty Departments (Leninism, } \\
\text { Dialectical Materialism, Political } \\
\text { Economy) }\end{array}$ & 23 & 2 \\
\hline $\begin{array}{l}\text { Military Department and of the } \\
\text { Department of Physical culture }\end{array}$ & 4 & 2 \\
\hline No data available & 3 & 100 \\
\hline Total & 168 & 4 \\
\hline
\end{tabular}

Table 3. Social background of repressed LGU teachers

\begin{tabular}{|l|c|c|}
\hline \multicolumn{1}{|c|}{ Social origin } & Number of teachers repressed & \% of teachers repressed \\
\hline Hereditary nobles & 21 & 13 \\
\hline Clergy (priests) & 9 & 5 \\
\hline Industrial bourgeoisie and merchants & 6 & 4 \\
\hline $\begin{array}{l}\text { Petty bourgeoisie, including personal } \\
\text { nobility and honorary citizens }\end{array}$ & 71 & 42 \\
\hline Working class & 15 & 9 \\
\hline Peasants & 31 & 18 \\
\hline Working class and peasants combined & 46 & 27 \\
\hline No data available & 15 & 9 \\
\hline Total & 168 & 100 \\
\hline
\end{tabular}

29 See Personnel records of workers, employees, academic teaching staff dismissed in 1917-1941: Lichnye dela rabochikh, sluzhashchikh, professorsko-prepodavatel'skogo sostava, uvolennykh v 19171941 gg. // Ob"edinennyi arkhiv SPbGU. F. 1. Op. 3.

${ }^{30}$ For this group of teachers, affiliation to a particular Faculty or Department is not indicated in the orders of the Director of LGU.

${ }^{31}$ One of the estates in the Russian Empire - a privileged stratum of urban population.

32 There is no information on the social origin in the personnel records of this group of teachers 
The values shown in the table indicate that, despite their class affiliation, people from the working-class background in the 1930s did not constitute the majority among the University teaching staff, although their number was gradually increasing. The relatively small percentage of descendants of nobles and other "former estates" can be attributed to the fact that most of them were dismissed in the earlier years after the Revolution of 1917. However, the presence at LGU of at least $22 \%$ of the teachers belonging to so-called "exploiters' classes", namely the nobles, clergymen, merchants and industrial bourgeoisie shows that in the early years of the USSR the Soviet education could not manage without these "former estates" as they were necessary to train the teachers from working and peasant background. In general, the backbone of the University teaching staff in the 1930s was made up of the descendants of middle-class urban population.

It is equally important to analyze how the party affiliation of LGU teachers could affect the likelihood of them being arrested and subjected to political repressions. To sum up on the basis of this part of the statistics, it can be concluded that teachers in most cases were repressed regardless of their membership in political parties. Belonging to the $\operatorname{VKP}(\mathrm{b})$ did not guarantee "immunity" from political repressions since almost a third of the arrested LGU teachers (28\%) were full-fledged members or candidate members ${ }^{33}$ of the VKP(b). During the investigation, they were accused of participating in internal party opposition groups headed by Trotsky, Zinoviev, Bukharin and other opposition leaders. More than a half of the arrested teachers were non-partisan (56\%), and $6 \%$ of them previously had belonged to other parties, such as the Mensheviks, Socialists-Revolutionaries, Socialists-Revolutionaries-Maximalists, Jewish Labour Bund ${ }^{34}$ and some others ${ }^{35}$. Thus, it cannot be argued that political repressions targeted exclusively non-partisan individuals, members of the $\operatorname{VKP}(\mathrm{b})$ or of any other party. From the point of view of the investigative bodies, it was logical since the internal party opposition, namely Trotskyists, Zinovievites, and Bukharinites, was no less dangerous for the authorities than the former "exploiters' classes".

When examining the logic of political repressions at LGU, it is also important to verify the hypothesis that those teachers who had experience of underground and subversive work before the Revolution as well as those with the experience of the military service, were the first to be arrested. Given the assumption that the authorities were really afraid of counter-revolutionary plots and terrorist attacks, teachers with such characteristics should have been under suspicion in the first place. However, statistics on repressions at LGU show that only $11 \%$ of repressed teachers in the past were underground revolutionaries, and $35 \%$ of them served in the army (the old Army, the Red Army, in rare cases even in the armies of white governments) ${ }^{36}$. Thus, less than half (46\%) of the repressed teachers were either active revolutionaries or combatants in the Russian Civil War and World War I, which also does not allow us to consider this group of teachers the only target of political repressions at LGU.

Summarizing this analysis, we can make an average socio-demographic "portrait" of a repressed LGU teacher. Most often, this was a middle-aged man (about 40 years old),

${ }_{33}$ Members who were on probation for some time before becoming full members of the VKP(b).

34 The name of this party is frequently shortened to "The Bund".

35 See Personnel records of workers, employees, academic teaching staff dismissed in 1917-1941: Lichnye dela rabochikh, sluzhashchikh, professorsko-prepodavatel'skogo sostava, uvolennykh v 19171941 gg. // Ob"edinennyi arkhiv SPbGU. F. 1. Op. 3.

36 Ibid. 
Russian or Jewish by ethnicity, petty bourgeois in terms of the social origin, holding the position of associate professor or full professor, non-partisan and slightly less frequently - a member of the $\operatorname{VKP}(\mathrm{b})$ by the party affiliation.

At the same time, it is also interesting to analyze the investigation files of repressed teachers which can be found in the Archive of the FSB Department for St. Petersburg and the Leningrad Region. Most of the LGU teachers were accused of creating or participating in counter-revolutionary fascist, Trotskyist, and other conspiracies against the Communist Party and the Soviet government. According to the indictments, they were charged with anti-Soviet counter-revolutionary conversations and propaganda (article 58-10 of the RSFSR Criminal Code); participation in illegal meetings, recruitment and other organizational activity aimed at preparation of counter-revolutionary crimes (article 58-11 of the RSFSR Criminal Code); sabotage (article 58-7 of the RSFSR Criminal Code); espionage (article 58-6 of the RSFSR Criminal Code) and preparing terrorist acts against the leadership of the country and Leningrad, most frequently against Stalin, Molotov, Voroshilov, Kaganovich and Zhdanov (article 58-8 of the RSFSR Criminal Code) ${ }^{37}$. However, the most common among the charges were counter-revolutionary propaganda, participation in counter-revolutionary organizations, and terrorism, i.e. crimes under paragraphs 10,11 , and 8 of article 58 of the RSFSR Criminal Code. As a rule, several paragraphs of article 58 were mentioned in the indictment; usually it contained two or more of them.

As for the evidential basis, the investigation primarily used the confessions and self-incriminations of the teachers under investigation as well as incriminations by other suspects, who in most cases were also accused of committing similar crimes and were under arrest themselves. From the perspective of the then judicial system, this fact could not cast doubt on the testimony of such "witnesses", and in the context of expedited trial proceedings, the suspect did not have the opportunity to prove that these statements were obtained under pressure. According to the investigative materials, there could be from 2 to 30 such statements incriminating a person under investigation ${ }^{38}$.

The role of classic denunciations, i.e. reports of a crime by citizens who are not under arrest, is minimal in investigative materials, although such denunciations rarely can be found in the case files of LGU teachers. Sometimes the files also contain minutes of various $\operatorname{VKP}(\mathrm{b})$ meetings, i. e. those of the primary party units, district committees or city committees, where the suspects were often harassed and bullied by their colleagues, but these transcripts comprise a relatively small proportion.

When obtaining confessions from the suspects, the investigation almost always tried to represent meetings of fellow teachers (in the working environment or in any other public place, as well as at home, in their apartments) as an "illegal gathering" of counter-revolutionaries, thereby "reclassifying" the meetings of colleagues at work into organizational meetings of terrorists. Thus, using this tactic, the NKVD bodies "identified" several counter-revolutionary groups at the University, which in total included more than $15 \%$ of the LGU teaching staff.

Of course, in terms of common sense it is not possible to trust all the confessions to terrorism, sabotage and espionage that are contained in the transcripts of the suspects' interrogations. Otherwise, it may turn out that in the 1930s of the $20^{\text {th }}$ century there were several counter-revolutionary organizations operating at LGU simultaneously, and the

37 See case files of LGU teachers: Arkhiv UFSB Rossii po SPb i LO.

38 Ibid. 
University was literally stuffed with conspirators, spies, saboteurs and terrorists. Moreover, according to the investigative materials, this large terrorist network extended beyond the LGU and covered almost all universities and research institutes in Leningrad. In reality, although we can assume that there could have been a large number of University teachers critical of the authorities, this does not allow us to claim that more than $15 \%$ of LGU employees were planning terrorist attacks and political assassinations of the highest party leadership of the country and the city, or that they were engaged in espionage and sabotage.

Interestingly enough, the severity of the sentence often depended on whether the suspects pled guilty or not. Those who fully admitted their guilt were mostly executed, and those who denied the charges during interrogations or recanted their statements at the court session were mostly sentenced to imprisonment or correctional labor camps for a period of 3-10 years ${ }^{39}$. Of course, pleading not guilty was not a guarantee of a more lenient sentence for all the suspects. However, the number of LGU teachers sentenced to capital punishment among those who did not plead guilty was significantly lower. For example, among the LGU teachers who fully admitted their guilt, more than a half were eventually shot, and most of those who did not plead guilty avoided the death penalty.

Ironically, for the investigative bodies the physical evidence was not a decisive factor, even in examination of such serious charges as terrorism. Short-barreled firearms that could theoretically be used for a terrorist attack were found in the homes of only a few LGU teachers during their arrests and searches. For example, the Dean of the Faculty of History, S. M. Dubrovsky, was found to have an unregistered Mauser ${ }^{40}$, and the Associate Professor of the same faculty, N. F. Pechersky, kept two pistols in his apartment, a Browning and a Korovin ${ }^{41}$. According to the interrogation transcripts, Professor Yu. Krutkov kept a revolver that belonged to the Dean of the Faculty of Physics V. R. Bursian, but at the confrontation the latter categorically denied this fact, and ultimately, the revolver was not joined to the case $^{42}$.

Thus, in most cases, no material evidence was presented by the investigation: among the items seized during the searches were mostly documents, personal letters, counter-revolutionary literature (books by Trotsky, Zinoviev, Bukharin and other opposition leaders) as well as manuscripts of the scientific works of the suspects themselves, which were often destroyed by NKVD officers during the search. Since personal correspondence was subject to destruction and did not appear in the case files as physical evidence later, it can be concluded that there was nothing criminal in it.

Some LGU teachers appeared to be in possession of several types of long-barrel firearms such as hunting weapons, Berdan rifle, small-caliber rifle and cartridges for them, which were found, for example, at the apartments of Associate Professor of the Faculty of Geology, Soil and Geography S. V. Voskresensky ${ }^{43}$; Professor of Dialectical Materialism P.L.Kucherov ${ }^{44}$; Associate Professor of the Faculty of Geology, Soil and Geography

\footnotetext{
39 Ibid.

40 Arkhivno-ugolovnoe delo Dubrovskogo S. M. // Arkhiv UFSB Rossii po SPb i LO. D. П-52073. L. 4.

41 Arkhivno-ugolovnoe delo Pecherskogo N. F. // Ibid. D. П-26810: in 11 vols. Vol. 11. L. 3

42 Arkhivno-ugolovnoe delo Bursiana V. R. // Ibid. D. П-25447. L. 18.

43 Arkhivno-ugolovnoe delo Voskresenskogo S. V. // Ibid. D. П-24617. L. 3.

44 Arkhivno-ugolovnoe delo Kucherova P. L. // Ibid. D. П-18212. L. 3.
} 
V. I. Kaminsky ${ }^{45}$; Associate Professor of the Faculty of Physics P. P. Kuznetsov ${ }^{46}$; and Assistant Lecturer of the Faculty of Biology S. I. Gorshkov ${ }^{47}$. The Director of LGU M. S. Lazurkin kept an air gun "Haenel" 48 , which was discovered in his flat during the search. However, it is hardly possible to assume that these firearms could be used for terrorist attacks or assassinations, and consequently they did not appear in the cases as material evidence.

All the circumstances that were mentioned above do not allow us to claim that the repressed LGU teachers were involved in preparing terrorist attacks against the leadership of the party and the government. Of course, the absence of physical evidence cannot be an absolute guarantee of their innocence since in some cases material evidence does not exist at all. However, during the searches no significant quantities of weapons, explosives or other items that could be used to perpetrate the alleged terrorist attacks were found. This fact suggests that the teachers-terrorists existed exclusively in the imagination of the NKVD officers conducting investigation.

In most cases, when asked by the investigator what had actually been done to organize terrorist attacks, the suspects replied that they had not had enough time to do anything since they were arrested very soon. The preparation of terrorist attacks thus was reduced to so-called "illegal meetings", where the "perpetrators" discussed their plans. Nevertheless, the interrogation records do not disclose how exactly the LGU teachers had been planning to carry out those attacks without weapons and explosives.

At the same time, some of the arrested LGU teachers admitted that they had had specific plans to perpetrate "terrorist attacks", which also might have been the product of imagination of the investigators or the suspects themselves. For example, Professor of the Faculty of History I. S. Plotnikov during the interrogation revealed that he together with the "accomplices" from the Tolmachev Military-Political Academy (this counter-revolutionary organization allegedly consisted of 14 people) planned to drop bombs from an airplane on the Kremlin or other facilities where the leaders of the $\operatorname{VKP}(\mathrm{b})$ could have been located. In order to accomplish that, they established a connection with a military pilot hostile to the Soviet authorities. The same group of "terrorists" intended to infiltrate into military units of Don and Kuban Cossacks taking part in parades and celebrations, who had negative attitude towards the Soviet government, , in order to commit a terrorist attack on Stalin ${ }^{49}$.

Other groups of "terrorists" meanwhile firstly prepared physical elimination of S.M.Kirov, and then of A.A.Zhdanov, who replaced the former as the First Secretary of the Leningrad Regional Committee of the VKP(b). The Associate Professor of the Faculty of History N. F. Pechersky revealed under interrogation that the "counterrevolutionary organization" intended to have Kirov under observation during his visits to the Uritsky Palace (now - the Tauride Palace). According to this version, the terrorist attack could have been planned in the Tauride Palace, as at the time the premises of the High Party School, where some of the "conspirators" worked, were located there. However, according to the case file, Pechersky knew nothing about the "Nikolaev-Kotolynov terrorist group" that under the official version assassinated Kirov at the end of 1934. In addition to this,

\footnotetext{
45 Arkhivno-ugolovnoe delo Kaminskogo V. I. // Arkhiv UFSB Rossii po SPb i LO. D. П-14865. L. 3.

46 Arkhivno-ugolovnoe delo Kuznetsova P. P. // Ibid. D. П-27633. L. 3.

47 Arkhivno-ugolovnoe delo Gorshkova S. I. // Ibid. D. П-62510. L. 3.

48 Arkhivno-ugolovnoe delo Lazurkina M. S. // Ibid. D. П-3449. L. 3.

49 Arkhivno-ugolovnoe delo Plotnikova I. S. // Ibid. D. П-17548. L. 19-20.
} 
Pechersky kept at home two revolvers to prepare an assassination attempt on Zhdanov (both pistols are mentioned as material evidence in the case). To try out the firearms, the "terrorists" allegedly made training shooting outside the city, but the revolvers turned out to be faulty ${ }^{50}$.

N.S. Frolov, the Assistant Lecturer of the Faculty of History, who worked simultaneously in the Leningrad Regional Party Committee, also confessed to have been planning a terrorist attack on Zhdanov after Kirov's assassination. He managed to keep Zhdanov under observation in Smolny ${ }^{51}$ and, seizing the right moment, intended to approach him quickly; then, despite the presence of security, to fire a shot at point-blank range. Frolov belonged to the counterrevolutionary group together with Seidel, Tomsinsky, and Pechersky (all of them taught at the Faculty of History of LGU), who studied terrorist attacks committed by $19^{\text {th }}$-century Russian revolutionary political organization "Narodnaya Volya" ${ }^{\prime 2}$ as part of their conspiracy to assassinate Zhdanov.Their group was associated with other similar "terrorist organizations" in the Leningrad branch of the Communist Academy, in the Herzen Pedagogical Institute, in the All-Union Stalin Communist University, in Tolmachev Military-Political Academy, in Leningrad Institute of Philosophy, Linguistics and History, and even in the Academy of Sciences ${ }^{53}$. As we can see, the "terrorist network" covered a significant part of the educational institutions in Leningrad.

Another extensive network of "counter-revolutionary organizations" that covered various Soviet educational institutions in Leningrad was described in the testimony of Professor of the Faculty of History L. F. Spokoinyi. In addition to LGU, this "terrorist structure" spread its tentacles into the Academy of Sciences and its institutes, into the State Academy for the History of Material Culture, into the Military Medical Academy, into Ioffe Physical-Technical Institute, into Leningrad branch of the Communist Academy, into Leningrad Institute of Philosophy, Linguistics and History, and into Tolmachev Military-Political Academy. The "terrorists" also penetrated into the Leningrad City Committee of $\operatorname{VKP}(b)$, and all these illegal groups were headed by the former Dean of the Faculty of History, G.S. Seidel ${ }^{54}$. During the trial, L. F. Spokoinyi did not deny that "he personally had taken part in the preparation of the assassination attempt on Stalin", and as a result he was sentenced to capital punishment and executed ${ }^{55}$.

The "terrorist network" of about the same scale emerged under the leadership of Professor B. V.Numerov, who became the main "perpetrator" involved in the so-called "Pulkovo Affair". A. S. Sluchanovsky, the Associate Professor of the Faculty of Physics, who was a former student of Numerov and allegedly served as his proxy in the "counterrevolutionary organization", testified during interrogations that the terrorist group was comprised of 31 people who were scattered around eight various scientific and educational institutions in Leningrad. The organization, according to the interrogation records of Sluchanovsky, was engaged in transferring of classified defense materials to German intelligence as well as in planning terrorist attacks. Sluchanovsky himself was "recruited" as the physical perpetrator of the terrorist attack on Zhdanov when he was walking together

${ }^{50}$ Arkhivno-ugolovnoe delo Pecherskogo N. F. // Ibid. D. П-26810: in 11 vol. Vol. 11. L. 73-74, 79, 133.

${ }^{51}$ At the time the headquarters of the Leningrad Communist Party, effectively the city hall.

52 Translated into English as "People's Will".

53 Arkhivno-ugolovnoe delo Frolova N. S. // Arkhiv UFSB Rossii po SPb i LO. D. П-27226. L. 57-68.

${ }^{54}$ Arkhivno-ugolovnoe delo Spokoinogo L. F. // Ibid. D. П-32810: in 9 vols. Vol. 7. L. 9-12.

55 Ibid. L. 66-84. 
with his "accomplices" in the corridor of the Leningrad Mining Institute and discussing their counter-revolutionary plans. On the instructions of the organization, he even tried, albeit unsuccessfully, to keep Zhdanov under observation during the passage of his car along Sovetsky (now - Suvorovsky) Avenue, in order to find out the residence of the head of Leningrad. As a result, similarly to many other suspects in the "Pulkovo Affair", Sluchanovsky was sentenced to death penalty by the Military Collegium of the Supreme Court ${ }^{56}$.

Another "terrorist" who was preparing the assassination attempts on Soviet leaders was Professor of Physics P.T. Sokolov. In his own testimony and during interrogations, he admitted that he had been a member of a "counter-revolutionary fascist organization", which alongside him included 14 other scientists. Also, he accepted the task of making a bomb in the seismic laboratory of the Central Research Institute of Geological Prospecting, where the explosives were kept ${ }^{57}$. On the instructions of the organization, he allegedly was supposed to make projectiles that were small enough to be carried in the pocket, since it was impractical to use a revolver. In addition, according to the case file, Sokolov developed plans for terrorist attacks on the leadership of the $\operatorname{VKP}(b)$; undertook Stalin's assassination; was aware of the preparation of an assassination attempt on Zhdanov; and was engaged in espionage and sabotage in the field of mineral prospecting. At the trial, Sokolov pleaded guilty to almost everything except for his role as the physical perpetrator of an attack and espionage. It is not surprising that with such a set of charges he was executed, as many others, on the day of being sentenced to death penalty.

Another "teacher-terrorist", Professor of Physics at LGU V.K. Fredericks, who was a distant relative of the last Minister of the Imperial Court of the Russian Empire, count V.B. Fredericks, confessed during interrogation that together with other members of the "counterrevolutionary fascist organization", which included a total of 12 people, he had been planning to carry out a terrorist attack against Stalin during a personal reception in the Kremlin, where a delegation of scientists was supposed to be invited ${ }^{58}$. However, Fredericks was unable to reveal his "criminal plans" in detail during the investigation.

More detailed testimony on this issue was given by Associate Professor of the Faculty of Physics Yu. N. Lepeshinsky - it was with the arrest of Lepeshinsky in September 1936 that the so-called "Pulkovo Affair" started. Under the interrogation, he testified that at an "illegal gathering" in the Central Research Institute of Geological Prospecting "it was decided to make a fuss over any scientific work, discovery or invention of P. T. Sokolov (another participant in the "counterrevolutionary conspiracy" mentioned above), in order to be received by Stalin in the Kremlin. During this reception, Sokolov was supposed to carry out a terrorist attack" 59 . In addition to this, Lepeshinsky testified that he had given instructions to Sokolov to engage in sabotage, and as a result of all the charges put together - the establishment and management of a counter-revolutionary fascist organization, recruitment of terrorists, master-minding the terrorist attacks, etc. - Lepeshinsky was sentenced to capital punishment ${ }^{60}$.

${ }^{56}$ Arkhivno-ugolovnoe delo Sluchanovskogo A. S. // Arkhiv UFSB Rossii po SPb i LO. D. П-27631. L. $34,41,54,55$.

57 Arkhivno-ugolovnoe delo Sokolova P. T. // Ibid. D. П-27631. L. 54.

58 Arkhivno-ugolovnoe delo Frederiksa V. K. // Ibid. D. П-19503. L. 16.

59 Arkhivno-ugolovnoe delo Lepeshinskogo Iu. N. // Ibid. D. П-28401. L. 40.

${ }^{60}$ Ibid. L. 137-138. 
Similar confessions were made by V.I. Kaminsky, the Associate Professor of the Faculty of Geology, Soil and Geography. According to his self-incriminatory statements, he was a member of a "counter-revolutionary group" that made a bomb for terrorist purposes and planned to assassinate Stalin as well as to perpetrate a terrorist attack on Zhdanov at the October demonstration in Leningrad ${ }^{61}$. However, Kaminsky himself, according to the interrogation transcripts, did not dare to be a perpetrator of the terrorist attack, and the bomb that he had allegedly made did not appear as material evidence at the trial.

Associate Professor of the Faculty of Physics A.P. Konstantinov was charged with making a bomb disguised as a seismograph for the physical elimination of Stalin ${ }^{62}$. Since Konstantinov was known as the inventor of electric seismograph, this version put forward by the investigation is not surprising. Konstantinov fully admitted his guilt and was executed, although, according to the interrogation record, he did not do anything in practice to create a bomb. Meanwhile, his daughter and some of his colleagues for many years wrote petitions to various authorities requesting the release of the scientist. They believed that Konstantinov as a talented inventor ( he is considered to have been an inventor of electronic television in addition to seismographs), might have been still alive, working at a sharashka ${ }^{63}$.

The case file of the Dean of the Faculty of Physics V.R.Bursian also contains the testimony of belonging to a "counterrevolutionary organization" that in total compised 12 members. Primarily they were planning to physically eliminate Stalin, Molotov, Voroshilov and Kaganovich, although, according to the interrogation transcripts, Bursian himself did not know anything about the practical preparation of these attacks ${ }^{64}$. Associate Professor of the Department of Political Economy P. F. Babaylov made a partial confession to "counterrevolutionary conversations after drinking alcohol together" as well as to having organizational relations with Trotskyists. However, at the trial, he attempted to clear himself of these charges saying that perhaps counter-revolutionary conversations had taken place, but he was completely drunk and did not remember anything ${ }^{65}$. Nonetheless, it was all in vain and did not help him as the sentence, pronounced by the Military Collegium of the Supreme Court, was 10 years of imprisonment. In 10 months after being sentenced, he was executed by the decision of "Special troika", as his name was included into a "shooting list" together with 181 other prisoners.

M.P. Bronstein, the Associate Professor of the Faculty of Physics and a science popularizer, who pleaded guilty, was also sentenced to capital punishment. He allegedly participated in the "organization for the liberation of the intelligentsia", which "stood on the positions of terrorism". Despite the fact that Bronstein knew nothing about the practical preparation of terrorist attacks, such confessions were enough for a death sentence ${ }^{66}$. Hs wife, Lydia Chukovskaya, the daughter of a famous children's writer as well as members of the Academy of Sciences S. I. Vavilov and V. A. Fok, futilely appealed to various authorities asking to release the scientist, but by that time he was no longer alive.

${ }^{61}$ Arkhivno-ugolovnoe delo Kaminskogo V. I. // Ibid. D. П-14865. L. 25.

62 Arkhivno-ugolovnoe delo Konstantinova A. P. // Ibid. D. П-18240. L. 16-17.

63 A secret research and development laboratory operating within the Soviet Gulag labor-camp system.

${ }^{64}$ Arkhivno-ugolovnoe delo Bursiana V.R. // Arkhiv UFSB Rossii po SPb i LO. D. П-19547. L. 10-16.

65 Arkhivno-ugolovnoe delo Babailova P. F. // Ibid. D. П-30712: in 2 vols. Vol. 2. L. 12-13.

${ }^{66}$ Arkhivno-ugolovnoe delo Bronshteina M. P. // Ibid. D. П-22962. L. 31-32. 
V.M.Gortikov, the Associate Professor of the Faculty of Biology, even admitted participating in two counterrevolutionary organizations simultaneously - "The Union of Young Russians" and "The National Union of the New Generation" associated with white emigrants and Trotskyist terrorist networks. Having confessed to the propaganda of terrorism, Gortikov actually signed up his own death warrant, although the investigation, like in many other similar cases, did not produce any physical evidence of his guilt ${ }^{67}$.

According to the handwritten testimony of the Dean of the Faculty of History A.K. Drezen, he was also a member of two "counter-revolutionary organizations" at the same time. As a Latvian by ethnic origin, Drezen was an active member of the Latvian national insurgent terrorist organization, whose goal was to create a "Greater Latvia" at the expense of the territory of the USSR and Estonia. He was also involved in the establishment of sabotage cells among the former Latvian Riflemen in Leningrad and near the Latvian border. However, according to his own confessions, Drezen had completely forgotten the Latvian language while working in Leningrad, which made it difficult for him to recruit Latvian Riflemen. In addition, Drezen admitted that he had been informed about Tukhachevsky's plot and had directly participated in it along with his brother who lived in Moscow. Together with the other conspirators, they planned to assassinate Stalin, Voroshilov, and Kaganovich, to arrest Molotov and Kalinin, and then to try them for state crimes $^{68}$. There is no doubt that these confessions were quite enough for a death sentence, and in the end Drezen was executed despite his working-class and peasant origin.

According to the materials of the confrontation, Professors of the Faculty of Physics P.P. Kuznetsov and S. P. Poletaev had even more sophisticated plans of "massive terrorist attacks" on Soviet leaders. Kuznetsov testified that they had intended to assassinate the leadership of the $\operatorname{VKP}(\mathrm{b})$ "not shooting them individually, but firing a machine gun and throwing bombs during public holidays, when all the Soviet leaders were in the stands" ${ }^{\prime \prime}$. Not surprisingly, Kuznetsov was sentenced to capital punishment, but Poletaev was luckier as he received a 10 -year prison sentence ${ }^{70}$.

Another important issue concerns the role of guilty pleas in political repressions. Apparently, in order to make the suspects plead guilty, the investigative authorities exerted psychological and sometimes physical pressure on them. According to the convicts who returned from Gulag, in some cases the torture was also used. However, it is possible that the pressure exerted on each suspect was different and depended on the investigator. The torture must have been used not very often, since otherwise, all or almost all of the suspects would have admitted their guilt. For example, in the testimony of Professor of the Department of Dialectical Materialism T.N.Gornstein there is no mention of the use of torture against her, although she heard screams and sounds of beatings from neighboring cells at night. Therefore, she assumed that physical methods were used against some of the suspects $^{71}$. Despite nine interrogations and five months of pre-trial detention, Gornstein denied all charges of terrorism and admitted connections and meetings with Trotskyists only at work. At the same time, in contrast to her, Gornstein's husband I. A. Weisberg con-

${ }^{67}$ Arkhivno-ugolovnoe delo Gortikova V.M. // Arkhiv UFSB Rossii po SPb i LO. D.П-18552: in 2 vols. Vol. 2. L. 1-2.

68 Arkhivno-ugolovnoe delo Drezena A. K. // Ibid. D. П-28374. L. 85-111.

69 Arkhivno-ugolovnoe delo Kuznetsova L. L. // Ibid. D. П-27633. L. 64.

70 Arkhivno-ugolovnoe delo Poletaeva S. P. // Ibid. D. П-27636. L. 203.

71 Gornshtein L.Z. Nochnoi dnevnik. P. 33. 
firmed the "organizational link" of his wife with the Trotskyists and denounced her as "a participant of Trotskyist illegal gatherings"72.

According to another suspect, Professor of Physics at LGU P. I. Lukirsky, who at the same time held the post of the Director of Physics Research Institute, "illegal investigative methods" were used against him as he was deprived of sleep and forced to stay upright for many hours in a row, sometimes for more than a day ${ }^{73}$. However, Lukirsky did not complain about having been beaten during pre-trial detention ${ }^{74}$. The screams of other prisoners were also heard by LGU Associate Professor M. M. Yermolaev, who was deprived of sleep and forced to "stand for days" in a solitary cell ${ }^{75}$. As we can see, not all the suspects pleaded guilty, and thus we can conclude that the pressure of the investigation exerted on them could be different.

As a rule, the investigation had enough time to obtain the necessary evidence as the pre-trial detention could last from 2 to 10 months. During this time, the suspect could have been interrogated up to 9 times, as normally in the case files of the LGU teachers several interrogation transcripts can be found. In reality, according to some suspects (for example, Professor of Mathematics N.I.Idelson ${ }^{76}$ ), the number of interrogations could have been even larger since the information obtained during several interrogations was compiled in a single transcript. For example, the case file of Professor P.I.Lukirsky contains only two transcripts of interrogation, but judging by the text of these documents it is clear that the suspect was interrogated many times: "for a long period of time you denied that..."77 With such long pre-trial detention and numerous interrogations, the investigators could obtain confessions without using the torture itself, but by creating such conditions for the suspects when they would be ready to confess to everything themselves.

Most of interrogation transcripts share several similarities: at the first interrogation, the suspects usually strongly denied participation in counter-revolutionary organizations, but later most of them gradually admitted to counter-revolutionary conversations first, then - to approval of terrorism as a method of fighting against the Soviet government, and finally confessed to planning terrorist attacks on the country's top leadership. It is highly unlikely that such confessions, which in fact guaranteed the suspects either the death penalty or a long-term imprisonment, were obtained without putting physical or psychological pressure on them. For example, Associate Professor of the Faculty of Geography M.M. Yermolaev wrote in his memoirs that he had pleaded guilty in order not to go through so-called "processing" by the interrogators one more time ${ }^{78}$. In his testimony, he deliberately called himself a French spy because he did not speak French. In doing so, he hoped that at the court session the absurdity of such self-incrimination would become evident. However, he was wrong as it turned out that no one cared about such small details at the trial.

72 Arkhivno-ugolovnoe delo Gornshtein T. N. // Arkhiv UFSB Rossii po SPb i LO. D. П-38815. L. 109, 124.

${ }^{73}$ Frenkel $^{`}$ V. Ia. Trudnye gody Petra Ivanovicha Lukirskogo // Zvezda. 1996. No. 10. P. 185.

${ }^{74}$ Lepeshinskaia V.N. Oskolki vospominanii. Chteniia pamiati A. F. Ioffe 1993-1995. St. Petersburg, 1995. P. 133.

75 Yermolaev M. M. Vospominaniia. P. 231-232.

76 Arkhivno-ugolovnoe delo Idel'sona N. I. // Arkhiv UFSB Rossii po SPb i LO. D. П-35013. L. 145.

77 Frenkel' V. Ia. Trudnye gody Petra Ivanovicha Lukirskogo. P. 188.

78 Yermolaev M. M. Vospominaniia. P. 236. 
The main suspect in the "Pulkovo Affair", Professor of Physics B. V. Numerov, in his complaint to the Prosecutor's Office, also wrote that he had been forced to sign false records containing only allegations without any substantial evidence. Having signed them, Numerov assumed that without any facts it would be impossible to find him guilty. The list of Numerov's "confessions" in the case file is huge as he was convicted under five paragraphs $(6,7,8,10$, and 11) of article 58 of the RSFSR Criminal Code. He confessed to working to overthrow the Soviet government and establish a fascist dictatorship, to recruiting terrorists, to counter-revolutionary propaganda, to subversion and sabotage, to industrial espionage for Germany and to using German agents in order to transfer classified information on some inventions, including those which were created by $\mathrm{Nu}-$ merov himself, as well as to many other terrible crimes. At the same time, later, while being in prison, Numerov in his petitions to various authorities pointed out a number of inconsistencies in his case. For example, according to the testimony of Associate Professor of Physics A.S. Sluchanovsky, who denounced Numerov as a counterrevolutionary conspirator, in June 1936 the latter allegedly took part in the "illegal meeting" in Leningrad, although in fact at the time Numerov was on an expedition and observed a solar eclipse ${ }^{79}$. Unfortunately, all Numerov's complaints and letters did not have any effect, and his case was not reviewed. Numerov was executed in Orel during the World War II on September 15, 1941 by the decision of the USSR Military Collegium of the Supreme Court, when German troops were approaching the city.

At the same time, the probability that these confessions may have been the result of a plea deal and in return the suspects may have been given certain promises cannot be ruled out. However, on the basis of the available case files it is hardly possible to say to what extent these promises were kept by the investigators.

Among the teachers under investigation were those who strongly denied all the charges and did not confess to anything. Therefore, it can be concluded that not all the suspects were tortured, and some NKVD officers did not aim at extracting confessions from them at any cost. For example, Professor of the Faculty of History G. V. Abramovich initially was told by the investigator that there was no substantial evidence against him, but later he was informed that the situation had changed, and a conviction was inevita$b^{8}{ }^{80}$. Despite the suspect's plea of not guilty, G. V. Abramovich was sentenced by the Special Council of the NKVD to 5 years imprisonment "for counterrevolutionary activities" but avoided the capital punishment. After serving his first sentence, he was re-sentenced to exile for three years, and upon completion of the exile, in the 1960s, G. V. Abramovich worked as a Director of a secondary school in Leningrad.

Assistant Lecturer of the faculty of Geology, Soil and Geography E. A. Popov, who also did not plead guilty, instead of putting his signature in the interrogation records, even dared to write "in this wording, I cannot sign it" ${ }^{\text {". }}$. Subsequently, at the trial, he categorically denied the charges of preparing a terrorist attack on Stalin but was nevertheless sentenced to 10 years in labor camps. Professor of the Faculty of History, N.I. Ulyanov,

${ }^{79}$ Arkhivno-ugolovnoe delo Numerova B. V. // Arkhiv UFSB Rossii po SPb i LO. D.П-23060: in 4 vols. Vol. 4. L. 206-207.

${ }^{80}$ This information is contained in the complaint of Gleb Abramovich, which he sent to the NKVD in order to obtain a review of the sentence. See: Arkhivno-ugolovnoe delo Abramovicha G. V. // Ibid. D. П-19347: in 2 vols. Vol. 1. L. 150.

${ }^{81}$ Arkhivno-ugolovnoe delo Popova E. A. // Ibid. D. П-18315. L. 22. 
who also denied organizational links with terrorists and counter-revolutionaries, got a relatively lenient sentence of 5 years in correctional labor camps ${ }^{82}$. His future was more fortunate as after being released N. Ulyanov managed to emigrate to the United States where he taught at Yale University and continued his career as a historian.

The former Dean and Professor of the Faculty of History, S. M. Dubrovsky, also vigorously denied all the charges. At the interrogation, he said that the investigation should identify real Trotskyists and conspirators instead of persecuting innocent people ${ }^{83}$. Since Dubrovsky was denounced by the testimonies of other suspects, he was sentenced to 10 years imprisonment, but luckily was not executed and after the death of Stalin worked as a historian in Moscow. Professor and the head of the Department of Dialectical Materialism A.G. Kogan ${ }^{84}$ as well as Professor of the Faculty of Biology E. M.Kreps ${ }^{85}$, also pleaded not guilty to participating in the Trotskyist-Zinoviev plot and received relatively lenient sentences of 5 years in correctional labor camps. As we can see, most of the LGU teachers who did not admit their guilt ultimately avoided capital punishment, and this tactic of behavior during the investigation was more advantageous for them.

Within the framework of the current article the role of various judicial and extrajudicial bodies that passed sentences on LGU teachers was also examined. Most of them were convicted at the field session of the Military Collegium of the USSR Supreme Court chaired by the corps military lawyer I. O. Matulevich, who was subsequently expelled from the Communist party and lost the rank of the Lieutenant-General of Justice for violation of the law in the period of mass repressions. Some suspects were tried by the Special Council of the NKVD (the so-called Special troika of the NKVD) and by the Commission of the NKVD and the USSR Prosecutor (the so-called "Big dvoika"). The last three bodies were extrajudicial, i.e. the decisions were made in absentia, without summoning suspects, and sentences were passed not individually but according to lists.

The Military Collegium of the Supreme Court, although being a judicial body, also used expedited trial proceedings. Only the suspect was brought before the Military Collegium, the defense and witnesses were not allowed, and the trial itself usually lasted from 20 minutes to 1 hour. It was also impossible to appeal against the verdict since according to the decree of the Presidium of the USSR Central Executive Committee "On the Procedure for Prosecuting the Cases on Preparation and Perpetration of Acts of Terrorism" of 1 December 1934, the suspects sentenced to capital punishment were supposed to be executed immediately either on the day of the trial or the next day.

Thus, there were only few substantial differences in the decisions of the Military Collegium and extrajudicial bodies as both of them used expedited trial proceedings and the suspects had little or no chances of proving their innocence in such circumstances. The only difference between them was that at the session of the Military Collegium the suspect could completely or partially recant his testimony or claim that he had signed the interrogation transcripts being in a "poor health". For example, Associate Professor of the Faculty of Geology, Soil and Geography S. V. Voskresensky recanted all the confessions he had made during the investigation, namely subversion and sabotage at the Hydrological Institute, preparation of terrorist attacks using hydrometric instruments, recruitment of

\footnotetext{
82 Arkhivno-ugolovnoe delo Ul'ianova N. I. // Ibid. D. П-71288. L. 20.

83 Arkhivno-ugolovnoe delo Dubrovskogo S. M. // Ibid. D. П-52073. L. 10.

84 Arkhivno-ugolovnoe delo Kogana A. G. // Ibid. D. П-21287. L. 23

85 Arkhivno-ugolovnoe delo Krepsa E. M. // Ibid. D. П-71715. L. 25.
} 
terrorists, and many others ${ }^{86}$. A similar course of action was chosen by Assistant Lecturer of the Faculty of Biology S. I. Gorshkov, who claimed at the trial that his testimony in the interrogation transcripts was not accurate, and that he had torn up the indictment handed to him after the end of the investigation to be signed ${ }^{87}$. As a result, Gorshkov and Voskresensky managed to avoid capital punishment and were sentenced to 10 years in correctional labor camps.

In a situation where the suspect did not plead guilty, he had to explain why the others gave incriminating statements against him. The key factor was whether the suspect and the denouncer were on bad terms or not. If there was no hostile relationship between them, it was almost impossible for the suspect to prove his innocence. For example, despite pleading not guilty, Professor of the Faculty of History M. D. Kokin was sentenced to capital punishment. At the trial he was unable to explain what motives the other suspects had had to testify against him ${ }^{88}$.

Another University lecturer, Professor of the Department of Dialectical Materialism P.L. Kucherov, claimed during the court hearing that all the incriminating denunciations had been a personal vengeance of those who had hostile relationship with him. In addition, he refused to sign the interrogation records because it was not indicated there that he had been opposed to Trotskyism before the arrest. Firstly, Kucherov was sentenced by the Military Collegium of the Supreme Court to 10 years imprisonment, but 10 months later he was executed by the decision of a Special troika of the NKVD of the Leningrad Region $^{89}$.

On rare occasions where the cases were referred to a regular court, a lawyer was involved in the litigation, and the suspects could expect more lenient sentences. For example, Professor of Mathematics N. I. Idel'son was sentenced by the Special Collegium of the Court of the Leningrad Region to only three years imprisonment under article 58-10 for counter-revolutionary propaganda ${ }^{90}$, and this was an extremely rare case when the suspect was not charged with anything else except "counter-revolutionary conversations". It can thus be concluded that at the time of political repressions in the 1930s, the severity of the sentence largely depended on the type of judicial body that considered the case.

The fate of many convicted LGU teachers was unfortunate since more than half of them were either executed or died while in prison. This happened, for example, to the Director of LGU M. S. Lazurkin, who, according to the investigation records, committed suicide by throwing himself out of the window during the interrogation ${ }^{91}$. Under another version, he was killed by the investigator while being interrogated, after which his body was thrown out of the window to stage the suicide ${ }^{92}$. We'll probably never find out what really happened there. However, Lazurkin's signature in the last interrogation transcript, where he allegedly admits being recruited by Bukharin as a member of the counter-revolutionary organization of the Right Opposition in Leningrad, is quite different from Lazurkin's signature in other documents, and most likely it was forged by the investigator.

${ }^{86}$ Arkhivno-ugolovnoe delo Voskresenskogo S. V. // Arkhiv UFSB Rossii po SPb i LO. D. П-24617. L. $162-170$.

${ }^{87}$ Arkhivno-ugolovnoe delo Gorshkova S. I. // Ibid. D. П-62510. L. 57.

${ }^{88}$ Arkhivno-ugolovnoe delo Kokina M.D. // Ibid. D. П-18317. L. 78.

${ }^{89}$ Arkhivno-ugolovnoe delo Kucherova P. L. // Ibid. D. П-18212. L. 30-31.

90 Arkhivno-ugolovnoe delo Idel'sona N. I. // Ibid. D. П-35013. L. 74.

${ }_{91}$ Arkhivno-ugolovnoe delo Lazurkina M. S. // Ibid. D. П-3449. L. 34.

92 Brim V.A. Sochineniia. Volgograd, 2007. 
Apart from that, the verdicts passed at the field sessions of the Military Collegium of the Supreme Court in 1936 could be revised later, and the convicts could be re-sentenced to stiffer penalties. According to the decision of Special troika of the NKVD and other extrajudicial bodies, capital punishment was applied to some teachers who were already serving their sentences. This is what happened to B. V.Numerov (the Professor of Physics and the Director of the Astronomical Institute), P.F. Babaylov (the Associate Professor of Political Economy), P. L. Kucherov (the Professor of Dialectical Materialism) ${ }^{93}$. Many of the convicted teachers after serving their sentences were exiled in the 1940s. This was the fate of T. N. Gornstein (the Professor of Dialectical Materialism), S. M. Dubrovsky (the Professor and Dean of the Faculty of History), S. V. Voskresensky (the Associate Professor of the Faculty of Geology, Soil and Geography), G. V. Abramovich (the Associate Professor of the Faculty of History) and some others ${ }^{94}$.

To sum up, we can draw a number of conclusions about the specific features of political repressions at LGU in the 1930s. Firstly, in percentage terms the scale of repressions at the University was approximately 10 times higher than in the USSR as a whole. This is due to the special attention of the NKVD and Soviet authorities to the intellectual elite to which the Leningrad professorship belonged. Secondly, within the current study it was not possible to identify the only "target group" of University teachers who were repressed in the first place. At the same time, most often the victims were middle-aged male teachers occupying the positions of Professor or Associate Professor, Russian or Jewish by their ethnic origin, while their party affiliation and participation in the Revolution of 1917 as well as their service in the armed forces were not predominant. Thirdly, it is quite obvious that most of the University teachers did not commit the crimes that they were charged with. As a rule, there was no physical evidence in the case files, and instead the NKVD mostly used confessions and incriminating statements of other suspects. Fourthly, the investigation sought to present any meetings of teachers at the University or elsewhere as "illegal gatherings of counter-revolutionary terrorists" who allegedly were making sophisticated plans for the physical elimination of Soviet leaders. At the same time, the severity of the sentence against LGU teachers depended primarily on which body - judicial or extrajudicial - was considering the case, and on whether the suspects pleaded guilty or not. In order to obtain the necessary confessions, it is highly likely that the suspects were subjected to psychological and physical pressure by the investigators, but the torture is unlikely to have been used against all the LGU teachers under arrest.

\section{References}

Amosova A. A. Rehabilitation of the Victims of Political Repressions (Based on the Records of the "Leningrad affair"). Noveishaia istoriia Rossii, 2011, no. 1, pp. 153-159. (In Russian)

Andreeva V.V. A Forgotten Name: the Destiny of a Young Historian and Ethnographer Evgeniy (Ein) Solomonovich Leibovich. Akademik A.S. Lappo-Danilevskii v pamiati nauchnogo soobshchestva. Eds V. V. Kozlovskii, A. V. Malinov. St. Petersburg, Intersotsis Publ., 2019, pp. 646-656. (In Russian)

Brachev V.S. Ia. M.Zakher Affair. Obshchestvo. Sreda. Razvitie, 2012, no. 2 (23), pp.41-45. (In Russian)

Brachev V.S. "The Affair” of Professor N.I. Ul'ianov (1904-1985). Obshchestvo. Sreda. Razvitie, 2013, no. 2 (27), pp. 53-57. (In Russian)

${ }^{93}$ See case files of LGU teachers: Arkhiv UFSB Rossii po SPb i LO.

94 Ibid. 
Brachev V.S. Historian Isaak Moiseevich Trotsky (1903-1937). Noveishaia istoriia Rossii, 2015, no. 3 (14), pp. 69-79. (In Russian)

Brachev V.S. Historian M.M. Tsvibak and his Destiny (1899-1937). Obshchestvo. Sreda. Razvitie, 2008, no. 2 (7), pp. 33-54. (In Russian)

Brachev V.S. Historian Vladimir Nikolaevich Kashin (1890-1938). Obshchestvo. Sreda. Razvitie, 2019, no. 2 (51), pp. 3-9. (In Russian)

Brachev V.S. The Road to Calvary of the Russian Historian. Member of the Academy of Sciences S. F. Platonov and his "Affair". St. Petersburg, Stomma Publ., 2005, 435 p. (In Russian)

Brim V. A. Writing. Volgograd, VGIPK RO Press, 2007, 224 p. (In Russian)

Frenkel' V. Difficult Years of Petr Ivanovich Lukirsky. Zvezda, 1996, no. 10, pp. 179-197. (In Russian)

Gessen V.Iu. The Tragic Fate of Aleksandr Alekseevich Voznesensky, a Rector of Leningrad University. Mavrodinskie chteniia - 2018. Materialy Vserossiiskoi nauchnoi konferentsii, posviashchennoi 110-letiiu so dnia rozhdeniia professora Vladimira Vasilevicha Mavrodina. Ed. by A. Yu. Dvornichenko. St. Petersburg, Nestor-Istoriia Publ., 2018, pp. 598-602. (In Russian)

Gornshtein L.Z. The Night Diary. St. Petersburg, 2013. 155 p. (In Russian)

Ermolaev M. M. The Memories of Mikhail Ermolaev. Co-written with Tamara L'vova. Petrozavodsk, [s. n.], 2009, 255 p. (In Russian)

Korsakov S. N. Political Repressions in the Institute of Philosophy (1930-1940s). Filosofskii zhurnal. 2012, no. 1 (8), pp. 120-170. (In Russian)

Lepeshinskaia V.N. Fragments of Memories. Chteniia pamiati A. F. Ioffe 1993-1995. St. Petersburg, Fizikotekhnicheskii institut im. A. F. Ioffe RAN Press, 1995, pp. 125-135. (In Russian)

Luneev V. V. Criminality in the $20^{\text {th }}$ century. Global, regional and Russian trends: global criminological analysis. Moscow, Norma Publ., 1997, 497 p. (In Russian)

Skvortsov A.M. The Ruin of the Antiquity Circle in Leningrad (Based on the investigations' data from Federal Security Service records). Vestnik drevnei istorii, 2017, vol.77, no. 1, pp. 210-223. (In Russian)

Sobolev G. L., Khodiakov M. V. Losses of the Leningrad University during the Great Patriotic War. Vestnik of Saint Petersburg University. History, 2010, iss. 2, pp. 14-23. (In Russian)

Статья поступила в редакцию 15 января 2020 г. Рекомендована в печать 9 сентября 2020 г.

Received: January 15, 2020

Accepted: September 9, 2020 